\title{
Peace Culture of Ex-Combatant as an Alternative Program of Deradicalization in Indonesia. (A Case Study of Ali Fauzi Manzi)
}

\author{
Tan Evi ${ }^{1}$, Muhamad Syauqillah ${ }^{2}$, Jerry M. Logahan ${ }^{3}$ \\ \{t4n3vi@gmail.com ${ }^{1}$, muhamadsyauqillah@ui.ac.id ${ }^{2}$, jerrymarcellinus@yahoo.com $\left.{ }^{3}\right\}$ \\ 1,2,3 Terrorism Studies, School of Strategic and Global Studies, Universitas Indonesia
}

\begin{abstract}
Indonesia is facing a novel challenge in dealing with the life of former militants or ex-terrorists who have been released from their imprisonment of terror acts. Since the year 2000 until September 2015, 501 terror convicts released from the charges and 328 still in prison. Then, there are hundreds of Indonesian who were the ISIS sympathizers are about to come home from Syria and Iraq. This research is aiming to serve as one of the consideration for the government to recruit ex-terrorists or ex-combatant as an alternative for deradicalization program. Ali Fauzi conducted deradicalization through 'Peace Culture' and established a foundation for ex-terrorist and ex-combatant known as Yayasan Lingkar Perdamaian (YLP). He fostered around 96 ex-terrorists and ex-combatants. He helped them with the method of deradicalizing "Peace Culture" through face-to-face dialogue, providing communities for them and imparting digitalization to channel the millennials in their understanding of peaceful Islam.
\end{abstract}

Keywords: Ex-combatant, deradicalization, Peace Culture

\section{Introduction}

Indonesia is facing a novel challenge in dealing with the life of former militants or exterrorists who have been released from their imprisonment of terror acts. Since the year 2000 until September 2015, 501 terror convicts released from the charges and 328 convicts were still in the prison. Then, there are hundreds of Indonesian who were the ISIS sympathizers are about to come home from Syria and Iraq.

This research is aiming to serve as one of the consideration for the government to recruit ex-terrorists or ex-combatant as an alternative for deradicalization program through its 'Peace Culture' approach. This program could help to navigate terror criminals and ex-perpetrators of terrorism to turn their extremism ideology and set Indonesia free out of terrorism.

The method of deradicalization requires practical and effective steps in its implementation, because several incidents of terrorism recur with the same perpetrators. In this paper, the authors conducted qualitative research methods, case study, observation, interviews, documentation and literature studies. The interviewee is Ali Fauzi Manzi, a former terrorist bomb expert from Desa Tenggulun district of Solokuro, Lamongan. Surabaya.

The results show that Ali Fauzi conducted deradicalization through 'Peace Culture' and established a foundation known as Foundation of Peace Circle [Yayasan Lingkar Perdamaian] or YLP. A foundation for ex-terrorist and ex-combatant. Ali Fauzi fostered around 96 ex- 
terrorists and ex-combatants. In his village on August $17^{\text {th }}, 2019$, ex-terrorists, ex-combatants and their family, about 200 person joined a flag-raised ceremony.

He helped ex-terrorists and ex-combatants with the method of deradicalizing "Peace Culture" through face-to-face dialogue, providing communities for them and imparting digitalization to channel the millennials in their understanding of peaceful Islam. Peace culture of ex-terrorists and ex-combatant can be used as an alternative for de-radicalization program in Indonesia.

\section{Theoretical framework}

\subsection{Terrorism, Ex-Terrorist, and Ex-Combatant}

According to Forst (2009), terrorism is the use of violence or the threat of planned and unlawful use of violence against targets that have symbolic meaning in order to encourage political change through intimidation and destabilization or to destroy populations identified as opposing parties In Indonesia, terrorism is an act or threat of violence that sparks the state of terror or fear in a larger scope, which causes victims of individual or masses and or evoke damages and destruction over strategic vital objects, ecology, public or international infrastructure - under the motive of ideology, politics or security threat.

The person who conducts the terror acts is called as a terrorist. Whereas, the term 'ex-' or mantan in Bahasa Indonesia as cited from kbbi.web.id, literally means a former position, or someone who are no longer in the same position that he/she was previously incharged. In addition, based on statement from the The National Agency for Combating Terrorism or Badan Nasional Penggulangan Teorisme (BNPT) and Special Detachment 88, an Indonesian Special Forces counter-terrorism squad known as DENSUS 88, an ex-combatant is a person who has ever joined or participated a paramilitary training. This is different from the terrorist who might not have any paramilitary training in the Middle-East. Ex-combatant could be an ex-terrorist; however, this might not occur the other way around. There are combatants, like the case in Aceh, who did not have a chance to be involved in a real war, but merely they had ever experienced the paramilitary training.

\subsection{Deradicalization}

The government of Indonesia and its respective institutions including Non-Governmental Organization (NGO) or LSM are still struggling to formulate the deradicalization program, which is precisely targeted and applicable for all ex-terrorists and ex-combatants. The BNPT's Prevention Director, Brigjen Pol. Drs. Hamidin (2017) stated that deradicalization is a program aiming at neutralizing the ideologies of whom the minds were exposed to radicalism. The target is both the terrorists who are in the prison or those who have been released and free from the charges. The goal is to refine the radicalism thoughts which have occupied their being, so they could get back to be part of the whole society. Needless to say, not to give radicalism ideology a place to grow.

The government of Indonesia has actually started the deradicalization program in prison since 2014. The program includes da'wah, counter-ideology, and national insight according to Deputy for Prevention of Protection and Deradicalization of the National Counterterrorism Agency (BNPT) Maj. Gen. Abdul Rahman Kadir. But this program has actually been initiated 
by the government since 2011 through BNPT. The implementation is carried out in prison with the aim of terrorism prisoners who are in prison.

Deradicalization is coined from the word 'radical' or violence. Radical is 'any single unlawful act of physical power and or without any apparatuses that carry threat or danger to physical, psychological, and freedom of individuals, including the act that causes people fainted and helpless.' The threat of violence is any behavior through all means: speech, written, visual, symbols, or physical movement, with or without any electronic or non-electronic devices that can cause dread toward the people or society and or to repress the intrinsic freedom of any person or society. Shoddiq (2018) asserted that radicalism is an revolutionary act craving for a harsh alteration that could drastically overturned the existed social norms. He also stated that radicalism gives birth to terrorism. Then, the meaning of deradicalization itself is the reversion of the radicalization process that started from the recruitment, self-identification, indoctrination, and a perverted interpretation of jihad. Komjen Pol. Drs. Suhardi Alius, MH (2018) gave picture of a radicalization phases, as follows:

a) Pre-radicalization: A normal livelihood prior to radicalization

b) Self-identification: One initially begins to identify oneself towards the radical movement

c) Indoctrination; One begins to intensify and strengthen their ideology.

d) Jihadation: One starts to take action based on their convictions.

The government of Indonesia has also regulated the Law No. 5 Year 2018 [UndangUndang Nomor 5 tahun 2018] and an Article No. 43D which stated the definition of deradicalization. The deradicalization is defined as a well-planned, comprehensive, and continuous process which is conducted in order to omit or diminish the existing radical terrorism ideology. Deradicalization is addressed to the suspects, the defendants, the convicts, former convicts of terrorism, individual or group of people who have been exposed to the radical ideology of terrorism. The ministry or relevant body of government that are related to combatting terrorism work together and responsible for coordinating the deradicalization process. This deradicalization process has to pass the phase of identification and evaluation, rehabilitation, reeducation, and social reintegration, in which the goal could be accomplished through the development of national concept, religious and or entrepreneurship concept.

\subsection{Method of Deradicalization}

Terrorism is an extraordinary crime. Terrorism causes a wide and multidimensional effects toward the social, cultural, ecological, economy, and political aspects. This is true as various governmental and non-governmental institutions at the national and international level have explored and investigated the aftermath of terrorism. Therefore, extraordinary treatment on this issue is utmost importance. There are at least two vital definitions of deradicalization (Asep, 2019):

Dis-engagement which means to support the radical group to reoriented themselves through the social-cognitive changes, so they can grow out of the radical ideology towards the nonradical ideology.

De-ideologization, which means the omission of religious ideology out of the political ideology. Instead, the religious ideology consists core values that promote a message for peace.

According to Jerry (2019), the deradicalization methods in Indonesia including the nonMuslim context, which include the movement for interfaith dialogue has actually been optimal. The reality reflects that the interfaith dialogues has in any way, direct or indirectly develop a sense of understanding towards the differences and similarities among religious groups. The 
prominent distinction is the dimension of theological aspects and rituals, however, similarities are evident among religious groups which is the dimension of humanism. Each religion are upholding the safety, well-being, justice, and peace. The aspect of humanism is the one that should be advanced, as this is the meeting point of all religions. Interfaith dialogue is not in the area to seek the similarities from theological doctrines and rituals, as each religion is dissimilar in this respect. However, the most vital needs is to find the meeting point within the area of humanism. Furthermore, Prasetyo (2016) revealed the synergy of Military Forces (TNI) and Police (Polri) in deradicalization of terrorism in Indonesia. The TNI and Polri, along with all components within the nation work together to run the deradicalization program which aimed at the main goal to neutralize radical ideology. This is a multi-sectoral coordination which should also be based on the perspective of warning, detection, and immediate action against terrorism.

The deradicalization is not only for the imprisoned-terrorist or criminals under the rehabilitation process, this also include their family members and society in general. The deradicalization which means de-ideologization should be a program designed for spectrum of society. The indicators for the success of the program include the raising-awareness and capability to detect and prevent as immediate as possible on the danger or threat of radicalism spread by figures, supporters, and sympathizers of radical groups through conventional or even technological devices of internet, such as social media. According to a deradicalization mentor, Sholehudin, there are Nine Phases or Wisdom that are supposed to be done in the deradicalization, as follows:

1) Studying the origin of the case and its network.

2) Identifying the background of the relatives

3) Looking at with an equal respect.

4) Sharing love.

5) Approaching with heart.

6) Being a good listener

7) Reminding about the beauty of family

8) Utilizing knowledge: a different approach towards each individual

9) Nurturing with perseverance

Nevertheless, all of these do not guarantee ex-terrorists to not repeat the same act of terror. A sample case that was mentioned by Mayjen TNI Abdul Rahman Kadir at vice.com, there were 600 prisoners of terrorism released until 2016. However, only 184 of them were being monitored under the apparatus. Then, there was one case of the Molotov bombing in Samarinda last year that the terrorist is an Ex-terrorist criminals. Likewise, the incident of pressure cooker bomb attack in Bandung was also done by alumnus of the IS military training in Aceh. The authority has actually identified the terrorist, Yayat Chadiyat, but there was no monitoring to set for him, until he did the bombing in Cicendo. These conditions evoke critiques that the time has come for the government to figure out an effective alternative, especially for monitoring and deradicalization program.

\subsection{A Humanistic Approach for Deradicalization}

A humanistic approach for deradicalization emphasizes that in order to lead the terrorist towards the right direction does not always through the coercive or isolating the suspected target as a terrorist, or in other term 'social bond' pressure. 
Williams (as cited in Marsh et al, 2016) explicated that there are four elements based on Hirschi which are important as social bond in relation to people who follow the law, as mentioned below:

1) Attachments. The stronger the social and psychological bond, the less the possibility for the occurrence of crime. Individuals are more aware and sensitive towards other people's opinion.

2) Commitment: Individual who does not value the significance of commitment or has less commitment towards his or her couple, children, education, work, property ownership, and so on, are tend to conduct crime.

3) Involvement. This element refers to the extent a person involved in certain lifestyle or activities that do not break the law. The more conventional the person's activities are, the less likely he/she involved in the act of felony.

4) Belief. This element refers to any options that a person want to accept, including the law.

There are five indicators for measuring the success of deradicalization based on Elaine Pressman, a researcher from Public Safety Canada, in her study Risk Assessment Decision for Violent Political Extremism (2009), as told by Tito Karnavian:

1) Rejection toward a rigid ideology.

2) Rejection on the act of violence

3) The gradual changes on the goals towards non-violence

4) Motivations to ensure deradicalization

5) Community support throughout the deradicalization process.

Those indicators are not absolute, as the treatment for each terrorist or ex-terrorist also requires particular approach. Similarly, Ali Fauzi recognizes that some of the ex-terrorist are still radical even though they have been supported throughout the daily basis.

\subsection{The Culture of Peace}

Vita, Y. (2016) wrote that the General Assembly of UN has adopted the Declaration on the Culture of Peace in 1999. The declaration of the Culture of Peace (1998) stated: Culture of Peace is a set of value, attitude, tradition, behaviour, and way of life which reflects and inspires:

1) Respect towards life and human rights

2) Rejection against all acts of violence in any form and the commitment to prevent conflict by seeking the root of the problem through dialogue and negotiation

3) Committed to participate in the process of fulfilling the need of the current and future generations.

4) To respect and promoting the equality of rights and opportunities for women and men.

5) Acceptance on the rights of each individual for the freedom of expression, giving opinion, and information.

6) Admiration of the principles of freedom, justice, democracy, tolerance, solidarity, cooperation, pluralism, diversity, dialogue, and mutual-understanding among nations, ethnicities, religions, culture, and other parties as well as among individuals.

According to the Ambassador Anwarul K. Chowdhury, the founder of the Global Movement for the Culture of Peace (GMCoP) (2019), The Culture of Peace is a very important for the humankind and every one can create it. He simply stated: 
... The Culture of Peace as a concept and motivation means that every one of us have to take
a conscious effort to set peace and anti-violence as part of our daily life.

He also emphasized that peace should be thought as a separated or a distant things form our life. In addition, we should learn how to connect with other people without being aggressive, violence, disrespectful manner, ignorance, and without prejudice. Besides, it is also important to realize that without the existence of peace, the opportunity for us to redefine ourselves, to develop, to empower ourselves in the face of life challenges in either individually or collectively would be vanished. He considered this as a dynamic and positive participatory process in which "dialogue is promoted and conflict is solved with the spirit of mutual-understanding and cooperation."

... Every individual is equally vital in the process of transformation to secure the peace culture in this world. Every individual should be convinced that the cooperative acts without violence is possible. If one successfully solved the conflict without any violence at any time, so, this person has dedicated a great contribution for the world as this single act transfer anti-violence and cooperation with other individual. If repeated, this action will grow exponentially; becoming an even easier practice at any time choices are to be decided to deal with a particular circumstances, to solve conflict without violence.

\section{Research Methodology}

The discussion of the study employs qualitative-descriptive research design, which aimed at providing a general picture of an ex-combatant and his foundation through the peace culture. The ex-combatant in this study is Mr. Ali Fauzi, while the variable of this study is terrorism. The data collection method in this study involves interviews and documentation. Interviews was conducted to Ali Fauzi, while an interview and observation was also conducted to the informant, Ustadz Moh. Khozin about the pesantren (an Islamic boarding school) that he managed and Chief of Village, Mr. Abushole SPdi. regarding the YLP foundation, pesantren and about the ex-combatant, Ali Fauzi. In addition, several other interviews were conducted to the Wonokromo police officer, informant from BNPT, DENSUS 88 Anti-terror, representative of Ministry of Education and Culture, and other relevant informants. Meanwhile, the secondary data were collected from the literature - books, official documents from the government, other documents, journals, newspapers, magazines, and the internet.

In this study, the technique for confirming validity and reliability of the data were based on the triangulation of multiple data collection. According to Moleong (1994), triangulation is a technique to verify the validity of data by utilizing external data as the means for checking and comparing among data collected. There are four types of triangulation in order to check the validity of the data: data sources, methodological, investigator, and theory triangulation.

The data analysis followed these steps:

1) Data reduction: to summarize, categorize the primary data, and focus on the specific information and arrange the data systematically.

2) Display data: to show particular data in matrix, graphs, charts or network if necessary.

3) Data verification: to identify the pattern, find the related themes with similarities, comparison, and then conclude the analysis. 


\section{Discussion}

Terrorist attacks that happened in Indonesia until these days has not one-hundred percent stopped yet. The findings last year from the database of Terrorism and Counter-Terrorism (Deteksi-Indonesia.com), stated that there have been 17 terrorist attacks and 333 combating acts against terrorist throughout January 2017 until September 2018. Within that time span, 50 people died, 68 were injured, one was kidnapped, and six building were damaged. Since 1981 until May 2018, 391 people lost their lives, 1,231 were injured. Recent studies from Global Terrorism Index in 2018 found that among 168 countries, Indonesia ranked 42th out of 138 where terrorist attack have ever occurred.

For the terrorists, they believed that their action was a noble struggle and they called themselves as mujahid or a hero instead of a terrorist. Karl Marx's theory in Ritzer and Goodman (2008) asserted that religion is an ideology and religion is an opium of the people, which is easily get into confusion and even could become a guide for revolutionary movement. Those who are exposed with the radicalism, have a different understanding and to transform that ideology is not an easy task. According to Schmid (2016), the characteristics of terrorism is to evoke terror, to threaten, to force, and to provoke the targeted population with the aim to achieve disharmony condition.

According to an Emeritus Professor of Psychology from Indonesia, Sarwono (2012), terrorists in Indonesia do not suffered from mental disorder, they are ordinary people, and some are even highly intelligent. They are not psychopath because they are working as usual to earn income, have their own family, love their parents, and has an affinity. The only dissimilarity is the ideology of terrorism, which is unalike from the rest of the society.

Terrorists use various strategies and relentless technique to reach their goal. James Lutz and Brenda Lutz (2013) categorized four strategies of terrorist group: personal attack (aiming to harm and use simple weapon), kidnappings (abduction to embarrass the government or to blackmail for money or to rise the popularity of the group), bank robberies (primarily to steal money and also embarrass the government), hijacking (to gain attention from the mass media). Neumann (2007) stated different opinion on the strategies used by terrorist groups, including disorientation, which is to isolate the authority from the society and create the impression that the government cannot handle the chaotic situation. Target response, the strategy used to push the government to respond in a way that benefit the terrorist group. Gaining legitimacy, to utilize the media and political organization in order to induce emotional impact of the violence acts of terror by inserting political message and gaining a larger supports for their movement. In their writings entitled The Strategies of Terrorism in the book Contending with Terrorism: Roots, strategies, and responses, Kydd and Walter (2006) are specifically discussed the strategies of the terrorist group:

1) Attrition: used to convince the opponents party (non-population) that terrorist group is quite strong and clearly can evoke serious threat.

2) Intimidation: used to gain a greater social control over particular society. Commonly used to take over the ruling regime.

3) Provocation: used to overthrown the regime and make territorial changes, also to convince the society that the government is very cruel that the goal of radical terrorist can be allowed and to guarantee the support for the group.

4) Spoiling: used to ensure the efforts for peace agreement among the moderate leaders in the terrorist group and government will be fail. The end goal is to create territorial changes for establishing new government or to unite with other country. 
5) Outbidding: to gain support from the society by convincing them that the group is better than the other group. To defence their status quo, that is to secure the regime or territorial regulation from other party who are trying to undertake some adjustment.

These strategies were much censured. Behind the strategies, there is an ideology or philosophy that lead the terrorists to do the action. Indonesia experiences the fourth wave period of modern terrorism, which is religious wave. According to David Rapoport (2013), an expert of Terrorism study in his book 'The Four Wave of Modern Terrorism,' he stated that the power and unique characteristics of religion gives birth to Religion Wave has already happened in some countries with the upsurge of Islamic state in Iraq and Syria (IS) and Al-Qaeda. This group believe that 1979 has a significant meaning for them (e.g. Iran Revolution), which signal the beginning of new century for Islam where a redeemer will appear and trigger the uprising from the previous Islamic era. The brutal Islamic militant group like Ayatollah and the lost of Soviet Union proved that religion has a potential to 'destroy the most secular power.' In addition, there are also groups like Al-Qaeda with their affiliation: IS, Boko Haram, Hezbollah who are becoming the central of international attention since the beginning of religion wave. The prime target of the Islamic terrorist groups is the United States of America, which has been claimed to insult their holy land and hinder their goal to unite Muslim country.

Sinaga (2018) stated that the wave of religion in Indonesia can be seen at the time Abu Bakar Ba'asyir who lived in Malaysia came back to Indonesia and directly proclaimed his desire to establish Islamic State and re-claim 'Jakarta Charter' and rejecting the national ideology of Pancasila and The Republic of Indonesia. Thus, the influence of the radical group from other country is obvious. According to Sinaga, there are three most influential foreign radical groups - Ikhwanul Muslimin, Al-Qaeda, and ISIS. Islam external appeared for the first time in Aceh in 2010 with the name 'Al-Qaeda Serambi Mekkah'. They provoked through religious call and video in Youtube on March 8 ' $^{\text {th }} 2018$ 'Seruan Jihad dari Serambi Mekkah' (A Call for Jihad from Serambi Mekkah). Jammaa'ah Islamiah (JI) is also a part of Al-Qaeda network in Indonesia and Southeast Asia. Moreover, there is a horrifying influence as the IS appeared with the advanced weaponry. Bahrun Naim (originally from Solo) joined the IS, and through social media, he spread the perverted teachings to invite Moslems to do jihad, if they can go to Syria.

The terrorist who has finished their imprisonment, has now becoming a challenge for the Indonesian nation. Since 2000 to September 2015, there are 501 terrorist criminals who have been released from the prison and 328 are still in the prison. Then, there are hundreds IS sympathizers in Iraq and Syria and are about to come back to Indonesia.

From the discussion with a researcher from The Habibie Center and several other informants, it is found that there is one ex-terrorist criminals who have started the Culture of Peace method prior to Ali Fauzi. His name is Ustad Khairul Ghozali, who founded and coordinates the pesantren Al-Hidayah in Deli Serdang, Medan. He establish the pesantren with a reason to expiate his sin in the past, to secure the education of children whose parents' are formerly terrorists and create the pesantren as a model of deradicalization.

How did Ali Fauzi been exposed to radicalism and became a terrorist? Here is the summary of the interview with him.

Ali Fauzi was born on November $15^{\text {th }}, 1971$, in Lamongan. He is an ex-combatant, expert in bomb-maker which was trained in Afganistan. He was arrested in the Philippines and was punished for three years imprisonment for conducting terrorist attack. In the prison, he was badly treated and tortured, which led him to commit a revenge and the determination to do jihad was burning in his heart. Ali Fauzi is the youngest siblings of 13, was born from different mother of three other brothers who were also terrorists; Muchlas, Amrozi, and Ali Imron. Back in their 
hometown, Lamongan, they were coming from a wealthy family. After his past experience, Ali Fauzi has gone through all the deradicalization phases, including several methods that have been discussed above and especially the approach of soft-power, which has already transformed him toward non-radical and even helping the government to combat terrorism by deradicalization using in his own way.

There are three phases that led Ali Fauzi to radicalism. First, when he was sent to the Pondok Pesantren Al-Mukmin, Ngruki, Sukoharjo, Central Java, under the leader Abu Baakar Ba'asir, in which the boarding school follows the extremist Islam. Secondly, when he received a letter from Afganistan sent by his stepbrother, Ali Ghufron alias Mukhlas to be a type of 'true Muslim' and became like his brother who went to the battlefield against Unisoviet. His young spirit and strong bond of kinship as well as his admiration to Islamic figures such as Abdullah Sungkar and Abu Bakar Baasyir, follow by his pursuit of self-identification had brought him to the international terrorist group. Third, the fastest method that was felt by Ali Fauzi to become radical was the videos that he watched. Provocation videos consisted of the cruelness of the West towards Muslims, Unisoviet towards Moslems in Afganistan, war between Mujahidin fighters with Russian soldiers, Jewish ending up lives of Palestinians, Filipino soldiers killing people of Mindanao. In which all the videos were taken without questioning the truth, as the videos also help to indoctrinate the enemies that should be executed.

Similar comment was also stated by Ali Fauzi during the interview with Julie ChernoHwang in 2018:

... "When I was in the pesantren in Indonesia, I did not understand anything about jihad. Then, when I was in Luqmanul Hakim, I was introduced to the videos about war in Afganistan, Bosnia. From that, I started to get attracted to be like them.

Learning about jihad and videos about wars become a strong doctrine and ideology for young Ali Fauzi. He wanted to go to the war or do Jihad and born in the heaven by dying as syahid.

The culture of violence in the name of religion is not occurred without any cause, it has been developed and certainly originated from a man within his own environment. Spreading from only one individual, then to a small group and then a larger group. Anthropologist, Marvin Harris classified two different types of religions. First, the religion which allows the killing, for example militant ideology in conquering land or food. Second is the religion, which prohibit the act of killing people, a religion which believes in god that will protect those from destruction and natural disasters. There is also argument from Karl Marx in Ritzer and Goodman (2008), who asserted that religion is an ideology and religion is an opium of the people, which is easily get into confusion and even could become a guide for revolutionary movement.

Revolutionary movement can be followed in conscious state, preconscious, and unconscious state. Freud's analysis on the rationalization into seven types of egos explained that conscious or unconsciously, an individual can turn around a reality (Koeswara, 1991). Freud in Maghfur Ahmad (2011) also asserted that 'Religion is an expression of human's madness.' There are 20 indicators that can be a parameter to measure the 'tendency of extremism of a religion' classified by Schmid (2014):

1) Situate themselves outside the mainstream and reject the existing social, political or world order;

2) Seek to overthrow, with the help of a revolutionary vanguard, the political system in order to re-establish what they consider the natural order in society - whether this envisaged order be based on race, class, faith, ethnic superiority; 
3) Are usually in possession of an ideological programme or action plan aimed at taking and holding communal or state power;

4) Reject or, when in power, subvert the liberal-democratic conception of the rule of law; use the political space provided by it to advance their cause in efforts to take state power;

5) Reject universal human rights and show a lack of empathy and disregard for rights of other than their own people;

6) Reject democratic principles based on popular sovereignty;

7) Reject equal rights for all, especially those of women and minorities;

8) Reject diversity and pluralism in favour of their preferred mono-culture society;

9) Adhere to a any ends-justify means philosophy to achieve their goals;

10) Actively endorse and glorify the use of violence to fight what they consider "evil" and to reach their political objectives (e.g. in the form of jihad);

11) Show a propensity to engage in mass violence against actual and potential enemies when in power or when enjoying impunity;

12) Are single-minded, black-or-white thinkers who want to purify the world and demonise, debase and dehumanise their enemies in hate speech, characterising them as "inferior" and earmarking them, implicitly or explicitly, as expendable;

13) Subordinate individual freedoms to collective goals;

14) Refuse to engage in genuine (as opposed to tactical and temporal) compromises with the other side and ultimately seek to subdue or eliminate the enemy;

15) Exhibit intolerance to all views other than their own dogmatic one and express this in anger, aggressive behaviour and hate speech;

16) Exhibit fanaticism, portray themselves as threatened and embrace conspiracy theories without necessarily being irrational in their strategic choices;

17) Exhibit authoritarian, dictatorial or totalitarian traits;

18) Are unwilling to accept criticism and intimidate and threaten dissenters, heretics and critics with death;

19) Expect obedience to their demands and commands rather than allowing to subject their views and policies to discussion even within their own group; and

20) Have fixed ideas and closed minds and believe there is only one truth - theirs. In its pursuit, they are often willing to face punishment or even death and sometimes actively seek martyrdom.

It is obvious that these criteria could help us see how religious doctrines enter people's mind until they conduct act of violence in the name of religion or what is commonly termed as religious terrorism 'for the sake of sacred religious mission.' The key of success for Ali Fauzi to escape from the terrorism circle is when he was arrested in the Philippines. The punishment that he experienced in the prison was unbearable and when he was deported to Indonesia, he was vomiting blood, suffer internal injured, and he broke his ribs.

\section{... I remembered when I was sent to Brigjen Pol. Surya Dharma Salin as a special staff for combating bomb, there were also Kombespol Tito Karnavian, Kapolda Central Java and West Java. I was injected with anesthesia and after that I awoke in the very good hospital. There was no single police officer who hit me.}

The soft-power approach and humanistic from the police authority, changed his perspectives towards police officers. The hatred that was carved every day in the pesantren started to disappear because of the contradiction from what he was experiencing at that time. 
Those police officers treated him very well, visiting him and bring fruits, talked to him every single day.

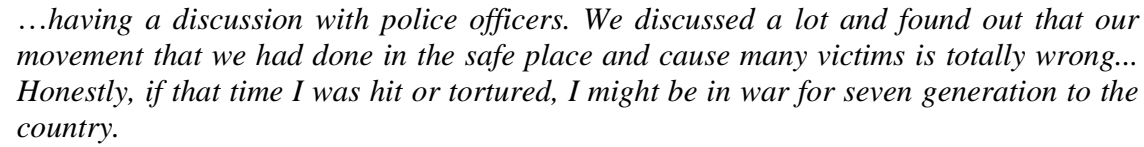

Afterwards, when Ali Fauzi started his study at Muhammadiyah University in Surabaya, he was exposed with a peaceful Islam.

\section{... Professor Sabib Muhri has opened his eyes on how other countries have advanced while} Islamic world are still underdeveloped at all.

Zainidin Maliki also taught him systematically until he transformed himself. He started to be more open because of environmental factor and friendships. He began to accept differences by making friends with non-Moslems, Christians, Hindu, and Buddhists. This has also been possible due to the accompaniment of all the faculty members, Mr. Habib and Mr. Samsul.

Navaro believed that the expansion of peace culture greatly influence the mindset that is required in the process of transformation that relies on the power of wisdom, from conflict to dialog and peace. This is in-line with the result of deradicalization process that were introduced by Ali Fauzi's lecturers.

Lastly, due to the victims of the bombing attacks. The meeting with the JW Mariot Victims, Mr. Febby during the participation of SAVE (Summit Against Violence Extremism) Program by the invitation of the Director of Google, John K in Dublin, Ireland, has opened the heart of Ali Fauzi.

.. When he shook my hand, Mas Febby with his damaged hand and face said "Mas Ali,
my face and hand is damaged (while showing it to me) because of the bomb assembled by
your students. At that time, my heart broken apart, and I hugged Mas Febby and cried.

These three events has brought me to a mission to conduct a deradicalization program to the terrorist criminals and ex-terrorist criminals as well as ex-combatants, which was called as 'Peace Culture' in this study.

Ustadz Moh. Khozin said that Ali fauzi is different from the other three stepbrothers, that he helped teaching in the Pondok Pesantren Islam Al Islam, tenggulun Solokuro, Lamongan, East Java. The Pondok Pesantren has students and teachers from other regions of Indonesia. Ali Fauzi promoted a peace culture, initially when he came back to Indonesia, he listed about 40 names of the bombing attack, and asked permission to Densus 88 Anti-terror to accompany him visiting the victims one after another and to ask for request for forgiveness Even though it must be hard for the victims to forgive him. Ali was not alone, he decided to help AIDA Foundation, where he supported and fostered the victims of the bombing attacks to work together in campaigning peace in Indonesia.

$$
\begin{aligned}
& \text {... from there, our relationships have improved and sometimes they come to my place and } \\
& \text { we keep in touch regularly. }
\end{aligned}
$$

This study analyzed that the face-to-face dialogue between the ex-terrorist and victims of the bombing bear a fruitful result. Secondly, Ali Fauzi established YLP on March 29th, 2017, at one of the important moment of the groundbreaking of Baitul Muttaqin Mosque' renovation 
and the starting of the establishment of Garden for Al-Quran Study (TPA) in Solokuro, Lamongan. Badrus Soleh (2018) stated to the Habibie Center, the vision and mission of YLP are:

1) To provide a new community for ex-terrorists criminals and ex-combatants, so they will not be back the old community.

2) To empower, train, and support the ex-terrorists to be an ambassador of peace.

3) To promote and facilitate the reinforcement of relationship among ex-terrorist criminals to create a strong voice and unite for peace.

YLP which is located in his house, try to help ex-terrorists to re-define their lives into the right direction and create a positive value. The information for the Chief of Village in Tenggulun Village, Solokuro district, Mr. Abusholeh, said that previously, Ali Fauzi's group and his friends from YLP foundation did not take their action in Tenggulun Village, so they were safe from any terrorist attack. This was also articulated by the police officer at Polsek Wonokromo that the village is quite safe.

The findings from Sarwono (2012) on several criminals and ex-terrorists (the actor of Bomb Bali and some other 47 terrorists, which were spread across correctional institutions in Indonesia, and those who had been released from the institutions) concluded that to transform ideology is not an easy job. In certain case, some showed a total rejection. Even though deradicalization can be conducted, but the easier job to do is through disengangement. This requires a shift from the ideological basis to the behavioral foundation. The goal of Ali Fauzi in conducting dialogues is to generate the awareness of their behavior and to change their attitude back into non-radical and not doing the same act of terror. The inclusive dialogue covers peaceful Islam and peaceful jihadism. In addition, he also provided a space for those who have been released from terrorism charges to never come back into their old group and offer them a sense of comfort, acceptance, caring, and thoughtfulness until they found a peaceful 'brand-new group.'

... Sometimes the government did not touch until this phases... they only guide until the those ex-terrorist are set free from the prison.

According to Prof. Dr. Irfan Idris (2019), the strength of the ex-terrorists or ex-combatants in the deradicalization program is that they can explain in detail in regards of the most frequently asked questions, which is 'why were you becoming a terrorist?' Why and how did you manage to discharge from the radical group? Those who had experienced, gone through, and explored the realm of radical anarchism are the one who can answer these two questions.

Those who are under Ali Fauzi's tutelage have begun to realize and understand a peaceful Islam. They are also willing to acknowledge Pancasila and respects the national flag. On August $17^{\text {th }}, 2019$, about 200 ex-terrorists including their family participated in an flag-raising ceremony when the author arrived at the location.

Third, the culture of digital era which targets to educate and raise the understanding of peaceful Islam to millennials and also the involvement of ex-terrorists in breaking apart the cycle of terrorism. Young generation of Indonesians are the target for terrorist recruitment. Solahudin (2018) stated that 9 percent of the youth were exposed to radicalism through online media, twitter or youtube, and 91 percent via offline interactions, such as meeting, pengajian (Quran recital), visitation (based on the Interview conducted by Solahudin in 2017 on 75 terrorist criminals in 2015-2016). Radicalization via offline platform or face-to-face is more frequent because mostly happened during the Quran recital. A study in 2017 showed that 85 percent Online recruit conducted their action a year after the establishment of IS in social media. 
A quite strange phenomenon, however, this is reality. In 2015, we can see that the actors of terror from 2002 until 2013 conducted their first terrorist attack a year after joining actively in the terrorist group.

The media has also taken part in propagating to the young millennials as they sometimes forget to filter before they share the information. According to Lasswell: Propaganda is the broadcast sense the technique of influencing human action by the manipulation of representations. Here are some goals of propaganda:

1) To mobilize hatred against enemies

2) To perpetuate friendship within the ally

3) To perpetuate comradeship and if possible gaining cooperation from neutral party

4) To demolish opponents morals.

Terrorism can easily be infiltrated in this circumstances. Weimann (2006) stated that the terrorist can use media for the following intentions:

1) Data Mining: those who are freely looking and reading all the activities of mass, the amount and location

2) Networking the Terrorists: They will make their network even stronger. The grow from depending on their leader to be independent without the leader.

3) Recruitment and Mobilization: The action surely requires people to work and media social is among the definite tools to recruit people.

4) Instruction and Online Manuals: Social Media helps to support the learning process for making their actions, guidelines or technique to assemble weaponry and bombing is also complete there.

The Ministry of Communication and Informatics of the Republic of Indonesia has conducted a prevention management on the negative content, digital utilizing, blockade, and law enforcement. However, Indonesian people are not equally aware and conscious about filtering negative contents and even be provoked.

Ali Fauzi put his efforts to reach young generations with easy language and conducted interactive activities such as seminars on the campus, outdoor activities and videos, and photos and paintings. A video about Japanese impression regarding the victims of bombing attacks, different forms of peace in the Quran, so the young generations can have an opened-minded, and understand peaceful Islam. He does not work individually, he conducts this peace culture by affecting other ex-terrorist and ex-combatants.

It is quite often that he got a stigma that he is a traitor or police-polisher and and government. However, this does not weaken his spirit to keep doing peace culture because for him these all are part of repentance. He hoped that he did not only make the ex-terrorists find their home (Indonesia) but also rebuild their lives.

\section{Conclusion}

From the research and various relevant sources gathered, there can be concluded that excombatant, Ali Fauzi has contributed toward the efforts of deradicalization. The accomplishment that Ali Fauzi achieved in approaching and gaining trust from the terrorist criminals, ex-terrorist, ex-combatant can be seen from the approach of deradicalization of 'Peace Culture' through face-to-face dialogues.

This has served to create a community which help to educate the peaceful teaching in Islam to the young generation. This would be a great reference for BNPT to learn in detail the approach 
that Ali Fauzi has taken and could be an alternative program for deradicalization in Indonesia, especially for BNPT. The effort to involve the ex-combatants into the deradicalization process definitely requires a significant attention from the government.

In addition to ensuring that the former combatants have truly repented and are not included in their old networks, they also need a great trust in them so that they can involve them in the de-radicalization program. Ali Fauzi was one of those who could be said to be successful on their own using the method of deradicalizing the Culture of Peace.

\section{References}

[1] Ansori M.H, dkk.: Memberantas Terorisme di Indonesia, Praktik, Kebijakan dan Tantangan. The Habibie Center Jakarta (2019)

[2] Chernov-Hwang, Julie.: Why Terrorist Quit, the Disengagement of Indonesia Jihadist (2018)

[3] Forst, B.: Terrorism, crime, and public policy. Cambridge University Press (2008)

[4] Idris, Irfan, Deradikalisasi, Strategi dan Program Penanggulangan Terorisme (2019)

[5] Jonathan, R., \& White, J. R, Terrorism an Introduction.: Thomson Wadsworth, Canada. (2002)

[6] Kominfo.: Peran Kementerian Komunikasi dan Informatika dalam Penanganan Konten Radikalisme dan Terorisme, Jakarta, 6 Juli 2018. (2018)

[7] Koeswara, E.: Teori-teori Kepribadian. Bandung: PT. Eresco. (1991)

[8] Kydd, A. H., \& Walter, B. F.: "The Strategies of Terrorism." In Contending Terrorism, by Michael Brown. (2006)

[9] Lutz, J., \& Lutz, B.: Global terrorism. Routledge. (2013)

[10] Marsh, I., et al.: Theories of Crime. Oxon: Routledge. (2006)

[11] Moleong, L. J., \& Kualitatif, M. P.: Bandung. PT Remaja Rosda karya. (1994)

[12] Owen Cote Jr, Steven Miller and Sean Lynn-Jones. Cambridge: The MIT Press. (2010)

[13] Navarro-Castro, L., \& Nario-Galace, J.: Peace education: a pathway to the culture of peace. Center for Peace Education, Miriam College. (2010)

[14] Neumann, P. R., \& Smith, M. L. R.: The strategy of terrorism: How it works, and why it fails. Routledge. (2007)

[15] Rapoport, D. C.: The Four Waves of Modern Terrorism: In Terrorism Studies. pp. 63-82. Routledge. (2013)

[16] Ritzer, G. Goodman, D. J. Nurhadi (terj.).: Teori Sosiologi: Dari Teori Sosiologi Klasik Sampai Perkembangan Mutakhir Teori Sosial Postmodern. Bantul: Kreasi Wacana. (2008)

[17] Sarwono, Sarlito Wirawan.: Terorisme di Indonesia: Dalam Tinjauan Psikologi. Pusataka Alvabet. (2012)

[18] Schmid Alex, P.: The Revised Academic Consensus. Definition of Terrorism. (2016)

[19] Sinaga, Obsatar dkk.: Terorisme Kanan Indonesia, Dinamika dan Penanggulangannya. PT. Elex Media Komputindo. (2018)

[20] Sholehudin.: 9 Wisdom Deradikalisasi Terorisme, Daulat Press Jakarta. (2019),

[21] Shodiq, H.MD.: Paradigma Deradikalisasi dalam Perspektif Hukum. Pustaka Harakatuna. (2018)

\section{Articles}

[1] Prasetyo, D.: Sinergi TNI-Polri dalam Deradikalisasi Terorisme di Indonesia. Jurnal Keamanan Nasional, 2(1), 35-58 (2016). Accessed, September 18, 2019

[2] Schmid, A. P.: Violent and non-violent extremism: Two sides of the same coin. Research Paper. The Hague: ICCT (2014). Accessed, September 18, 2019

[3] Solahudin.: Terrorism 'zaman now': is social media feeding radicalisation? (2018). Accessed, September 18, 2019 
[4] Vita, Y. (2016).: Penanaman Budaya Damai Via Pendidikan. Dimas: Jurnal Pemikiran Agama untuk Pemberdayaan, 14(1), 17-28. (2016). Accessed, September 18, 2019

[5] Weimann, G. (2006):: Terror on the Internet: The new arena, the new challenges. US Institute of Peace Press. (2006). Accessed, September 18, 2019

[6] http://indonesiaatmelbourne.unimelb.edu.au. Accessed, September 18, 2019

[7] https://www.communicationtheory.org/lasswells-model/, Accessed, September 18, 2019

[8] https://www.indepthnews.net/index.php/opinion/2905-un-to-commemorate-20th-anniversary-ofthe-culture-of-peace-declaration\#.XYj7RpeurNk.linkedin, Accessed, September 18, 2019

[9]https://www.vice.com/id_id/article/78qbg4/lebih-dari-400-mantan-napi-teroris-tak-terpantaupemerintah. Accessed, September 18, 2019

[10] http://wahidfoundation.org/index.php/news/detail/Tito-Karnavian-dan-Tantangan-Deradikalisasi. Accessed, September 18, 2019

[11]https://damailahindonesiaku.com/apresiasi-masyarakat-dunia-untuk-indonesia-dalam-

penanganan-terorisme.html. Accessed, September 23, 2019

[12] www.hukumonline.com, Accessed, September 23, 2019

[13] https://www.kbbi.web.id/mantan. Accessed, September 23, 2019

[14] https://www.bnpt.go.id/direktur-pencegahan-bnpt-siapa-bilang-deradikalisasi-gagal.html.

Accessed, September 23, 2019

[15] https://www.deteksiindonesia.com, Accessed, September 18, 2019

[16] www.globalterrorismindex.org, Accessed, September 18, 2019

[17] Komjen Pol. Drs. Suhardi Alius, MH (2018). Kuliah umum "Resonansi Kebangsaan dan Bahaya

Serta Pencegahan Radikalisme”. 23 April 2018. UI Depok. (2018)

\section{Interview}

[1] Evi, T.: Personal interview. Abusholeh Spdi. (2019)

[2] Evi, T.: Personal interview. Dr. Asep Usman Ismail. (2019)

[3] Evi, T.: Personal interview. Dr. Jerry Marcellinus Logahan. (2019)

[4] Evi, T.: Personal interview. Ustad Ali Fauzi. (2019)

[5] Evi, T.: Personal interview. Ustadz Moh. Khozin. (2019)

[6] Evi, T.: Personal interview. Informan. BNPT. (2019)

[7] Evi, T.: Personal interview. Informan. DENSUS 88 Anti Teror. (2019) 